\title{
Cluster Analysis Applied to Climatology: A New Approach to Detect Changes in Precipitation
}

Susane Eterna Leite Medeiros ( $\nabla$ susane.eterna@gmail.com )

Federal University of Paraiba https://orcid.org/0000-0002-8776-9343

Priscila Farias Nilo

Wallysson Klebson de Medeiros Silva

Paula Rose de Araújo Santos

Louise Pereira da Silva

Raphael Abrahão

Research Article

Keywords: Climate Change, Multivariate Analysis, Trend Analysis, Mann Kendall, Precipitation

Posted Date: February 2nd, 2022

DOI: https://doi.org/10.21203/rs.3.rs-1289095/v1

License: @ (i) This work is licensed under a Creative Commons Attribution 4.0 International License. Read Full License 


\section{Abstract}

This work proposes a novel method for the application of cluster analysis to climatology. The new method groups similar years regarding total values of precipitation and distribution throughout the year. The most recent and oldest years are then compared to examine changes in the distribution pattern. The Ward's method was used to compose hierarchical clusters. Trend analysis encompassed the Mann-Kendall and Sen's slope tests to complement and compare the results. This test characterizing a simple random series. As a form of exemplification, the proposed method was applied to historical data from seven weather stations located in northeastern Brazil. Significant trends of both increase and reduction in precipitation were observed, depending on the station studied. Even for statistically non-significant trends, the new cluster analysis enabled the verification of more subtle changes in precipitation. This new approach to cluster analysis can provide a broader view on how changes in precipitation patterns are occurring.

\section{Introduction}

The identification and characterization of the climate of a region depends on several elements such as air temperature, air humidity, atmospheric pressure, and precipitation, which are influenced by geographical factors such as the type of relief, altitude and its continentality (Betts et al. 2014; Marengo et al. 2018; Krzysztof et al. 2020). Understanding the meteorological dynamics and its changes has been the subject of intense investigations, since climatic conditions interfere widely in various sectors such as economic, energy and agricultural (Dogru et al. 2019; Parker et al. 2019; Solaun and Cerdá 2019; Mtilatila et al. 2020).

In this context, there is a need for using tools that evaluate both spatial and temporal variability of these climatic variables. Thus, multivariate cluster analysis deserves attention, since it classifies objects or individuals into mutually exclusive subgroups, being widely used in data mining (Liu et al. 2019). Data clustering techniques make it possible to work with large samples, which keep the relevant information from the original dataset. These techniques can be separated into hierarchical, which perform successive groupings by decreasing or increasing the number of clusters, or non-hierarchical, which divide the data into a predetermined number of clusters (Hair et al. 2011).

Hierarchical techniques can be divided according to the cluster grouping criterion, and Ward's method is among the most common ones (Majerova and Nevima 2017). In general, this methodology has been used for meteorological data when the goal is to find homogeneous regions from the point of view of their peculiar characteristics. Statistical homogenization techniques are fundamental to capture similar characteristics and thus obtain a pattern of regionalized similarities.

Slightly changing this perspective, the clustering technique was used in the present study in an innovative way, together with trend analysis, in order to investigate the common and data grouping factors for precipitation. The objective was to have a better understanding of seasonal and interannual patterns, bringing together years with similar behavior in the same cluster, in addition to verifying the occurrence of changes in the climatic series. For exemplification, the method was applied to historical data from weather stations in the semi-arid region of the state of Paraíba (Northeastern Brazil).

\section{Material And Methods}

The Paraíba state is located between the meridians of $34^{\circ} 45^{\prime} 54^{\prime \prime}$ and $38^{\circ} 45^{\prime} 45^{\prime \prime}$ W and the parallels of $6^{\circ} 02^{\prime} 12^{\prime \prime}$ and $8^{\circ} 19^{\prime} 18^{\prime \prime}$ S, belonging to the Northeast region of Brazil. It is bordered to the north by the state of Rio Grande do Norte, to the west by Ceará, to the south by Pernambuco and to the east by the Atlantic Ocean (Fig. 1).

The state has an area of 56,585 km² and is divided into four intermediate regions: João Pessoa, Campina Grande, Patos and Sousa-Cajazeiras (IBGE 2017). The study area is located between the intermediate regions of Patos and Sousa-Cajazeiras.

The characteristic climate is predominantly semi-arid, As and BSh according to the Köppen-Geiger climatic classification, with marked intra-annual precipitation variability, with two distinct annual seasons: a dry one between June and January and a rainy one between February and May, with total annual precipitation normally less than $900 \mathrm{~mm}$. The maximum monthly values of precipitation occur in March and the minimum values between August and October (Alvares et al. 2013; Medeiros et al. 2018).

This study was conducted using the monthly historical precipitation data made available by the National Institute of Meteorology (INMET) and the Executive Agency for Water Management (AESA), from seven weather stations located in the municipalities of Água Branca, Aguiar, Coremas, Patos, Princesa Isabel, Sousa and Teixeira (Table 1).

Table 1 presents information about the weather stations chosen for this study, the municipality, its geographical location, altitude, the period of the series created with the precipitation data and the amount of years absent in each series.

The data were organized in annual discrete time series that were quarterly (December-January-February: DJF; March-April-May: MAM; June-July-August: JJA; September-October-November: SON) and monthly (every month from January to December). These series were subjected to a quality and reliability control process to verify and eliminate errors resulting from technical and/or data transmission problems. Only complete years were considered for this study, that is, the years in which there were precipitation data in all months from January to December, without exception. Incomplete years were excluded and represented between $1.9 \%$ and $36.8 \%$ of the series of the weather stations of Princesa Isabel and Sousa, respectively.

Table 1 Rain gauge stations used in the study 


\begin{tabular}{|lllllllll|}
\hline Number of station & Operator & $\begin{array}{l}\text { Station } \\
\text { (Municipality) }\end{array}$ & $\begin{array}{l}\text { Lat. } \\
(\mathbf{S}, \mathbf{X})\end{array}$ & $\begin{array}{l}\text { Long. } \\
(\mathbf{W}, \mathbf{X})\end{array}$ & $\begin{array}{l}\text { Altitude } \\
(\mathbf{m})\end{array}$ & Series interval (year) & Period (Years) & Number of absent years \\
\hline 737022 & AESA & $\begin{array}{l}\text { Água } \\
\text { Branca }\end{array}$ & -7.30 & -37.38 & 735 & $1936-2018$ & 78 & 4 \\
\hline 738025 & AESA & Aguiar & -7.05 & -38.10 & 262 & $1935-2018$ & 76 & 7 \\
\hline 737019 & AESA & Coremas & -7.00 & -37.56 & 218 & $1935-2018$ & 68 & 15 \\
\hline 82791 & inmet & Patos & -7.01 & -37.16 & 242 & $1977-2018$ & 26 & 15 \\
\hline 738013 & AESA & Princesa Isabel & -7.44 & -37.59 & 683 & $1912-2016$ & 102 & 2 \\
\hline 82689 & inmet & Sousa & -6.45 & -38.13 & 220 & $1961-2018$ & 36 & 84 \\
\hline 737002 & AESA & Teixeira & -7.13 & -37.15 & 768 & $1926-2018$ & 8 \\
\hline
\end{tabular}

To verify the existence of trends and describe the behavior of the time series, the Mann-Kendall nonparametric statistical test proposed by Sneyers (1992) was applied. This method is based on the hypothesis of stability of a temporal and discrete series in which the succession of its values occurs independently and whose probability distribution is always the same, characterizing a simple random series. In addition, Sen's linear regression method was applied as a quantifier to establish the magnitude of the trend from the slope of the line. Probabilities of error between $0.1 \%$ and $10 \%$ were considered (Kendall 1975 ; Mann 1945; Sen 1968).

Cluster analysis was applied to verify monthly and seasonal changes in historical series. For each rain gauge station, each month of the year was considered as a different variable and the Ward's method was used to compose hierarchical clusters. The intention was to allow the method to group the years that had a similar distribution of precipitation throughout the year (similar seasonality, with equivalent monthly values). The similarity measure was given from the mean squared Euclidean distance (Hair et al. 2011). After creating each cluster, the median year of the objects (month-year combinations) served as an indicator to compare the recent and past periods for each of the localities of this study. The number of clusters, between two and three, was chosen in order to facilitate the analyses, since the presence of many clusters would compromise the interpretation of the results.

The statistical procedures were performed with the programs Statgraphics 15 and Makesens 1.0 .

\section{Results And Discussion}

\subsection{Characterization and analysis of trends}

The average annual precipitation in the study area varies between $620 \mathrm{~mm}$ and $926 \mathrm{~mm}$ in the stations of Patos and Sousa, respectively (Fig. $2 a$ ). The distribution of the monthly average precipitation shows similar behavior in all rain gauge stations, with maximum values in March and minimum values between August, September and October, reinforcing when wet and dry periods occur, a common characteristic of semi-arid regions of Brazil (Fig. 2b).

Trend analysis is one of the most important measures in the study of time series data. In recent years, several methods have been developed and used in climatological studies to analyze trends in time series, such as linear regression, Mann-Kendall test, Spearman's rank-order correlation coefficient, Theil-Sen estimator, innovative trend analysis, among others (Gedefaw et al. 2018; Chervenkov and Slavov 2019; Shahid and Rahman 2021). Among these methods, the Mann-Kendall test is the most popular, due to its efficacy in identifying trends related to the variation of the sample and the magnitude of the trend itself (Wang et al. 2020a, b).

In the present study, the Mann-Kendall test showed statistically significant changes $(p<0.01)$ in the annual comparison for the stations of Água Branca and Teixeira, with increase rates in precipitation of $4.06 \mathrm{~mm} /$ year and $4.15 \mathrm{~mm} / \mathrm{year}$, respectively. In the other stations, the annual comparison showed no significant trends (Table 2).

In addition to these, in monthly comparisons it was also possible to observe changes in the distribution of precipitation. January (in Água Branca, Coremas and Teixeira), April (in Teixeira), May (in Água Branca) and July (in Água Branca and Princesa Isabel) showed increasing trends, with values between 0.15 $\mathrm{mm} /$ year $(\mathrm{p}<0.05)$ and $0.91 \mathrm{~mm} /$ year $(\mathrm{p}<0.05)$. The increases were concentrated from January to July (Table 2).

However, for March, the month considered with the highest average precipitation for the studied area (Fig. 2b), there was a significant trend of reduction in precipitation volume at a significant rate of $2.92 \mathrm{~mm} /$ year $(\mathrm{p}<0.10)$, only for the municipality of Sousa (Table 2).

Table 2 Trends detected through the Mann-Kendall test, quantified by Sen's slope, for the study area 


\begin{tabular}{|c|c|c|c|c|c|c|c|}
\hline Period & $\begin{array}{l}\text { Água Branca } \\
\text { (mm/year) }\end{array}$ & $\begin{array}{l}\text { Aguiar } \\
\text { (mm/year) }\end{array}$ & $\begin{array}{l}\text { Coremas } \\
\text { (mm/year) }\end{array}$ & $\begin{array}{l}\text { Patos } \\
\text { (mm/year) }\end{array}$ & $\begin{array}{l}\text { Princesa } \\
\text { Isabel } \\
\text { (mm/year) }\end{array}$ & $\begin{array}{l}\text { Sousa } \\
\text { (mm/year) }\end{array}$ & $\begin{array}{l}\text { Teixeira } \\
\text { (mm/year) }\end{array}$ \\
\hline January & $0.65^{\star \star}$ & $0.58 \mathrm{~ns}$ & $0.91 *$ & $1.57 \mathrm{~ns}$ & $0.20 \mathrm{~ns}$ & $0.79 \mathrm{~ns}$ & $0.60 * \star$ \\
\hline February & $0.44 \mathrm{~ns}$ & $0.54 \mathrm{~ns}$ & $0.21 \mathrm{~ns}$ & 0.73 ns & $-0.23 \mathrm{~ns}$ & -1.05 ns & $0.25 \mathrm{~ns}$ \\
\hline March & $0.25 \mathrm{~ns}$ & $-0.60 \mathrm{~ns}$ & $-1.16 \mathrm{~ns}$ & $-2.79 \mathrm{~ns}$ & $0.07 \mathrm{~ns}$ & $-2.92+$ & $0.10 \mathrm{~ns}$ \\
\hline April & $0.01 \mathrm{~ns}$ & $0.30 \mathrm{~ns}$ & $-0.41 \mathrm{~ns}$ & $0.30 \mathrm{~ns}$ & $0.11 \mathrm{~ns}$ & $-1.76 \mathrm{~ns}$ & $0.77+$ \\
\hline May & $0.65^{*}$ & $0.33 \mathrm{~ns}$ & $0.01 \mathrm{~ns}$ & $-0.35 \mathrm{~ns}$ & $0.11 \mathrm{~ns}$ & $0.08 \mathrm{~ns}$ & $0.18 \mathrm{~ns}$ \\
\hline June & $0.28 \mathrm{~ns}$ & $-0.09 \mathrm{~ns}$ & $-0.03 \mathrm{~ns}$ & $0.06 \mathrm{~ns}$ & $0.01 \mathrm{~ns}$ & $0.14 \mathrm{~ns}$ & - \\
\hline July & $0.35^{\star}$ & $0.00 \mathrm{~ns}$ & $0.02 \mathrm{~ns}$ & $0.00 \mathrm{~ns}$ & $0.15^{*}$ & $0.06 \mathrm{~ns}$ & - \\
\hline August & - & - & - & $0.00 \mathrm{~ns}$ & - & $0.00 \mathrm{~ns}$ & - \\
\hline September & - & - & - & $0.00 \mathrm{~ns}$ & - & $0.00 \mathrm{~ns}$ & - \\
\hline October & - & - & - & $0.00 \mathrm{~ns}$ & - & $0.00 \mathrm{~ns}$ & - \\
\hline November & - & - & - & $0.00 \mathrm{~ns}$ & - & $-0.11 \mathrm{~ns}$ & - \\
\hline December & - & $0.00 \mathrm{~ns}$ & $0.14 \mathrm{~ns}$ & $0.34 \mathrm{~ns}$ & $-0.02 \mathrm{~ns}$ & $-0.11 \mathrm{~ns}$ & - \\
\hline DJF & $1.82^{\star \star}$ & 0.82 ns & $1.67+$ & $2.80 \mathrm{~ns}$ & $-0.35 \mathrm{~ns}$ & $0.36 \mathrm{~ns}$ & $1.82^{* *}$ \\
\hline MAM & $0.82 \mathrm{~ns}$ & $0.04 \mathrm{~ns}$ & $-1.25 \mathrm{~ns}$ & $-5.96 \mathrm{~ns}$ & $0.68 \mathrm{~ns}$ & $-3.88 n s$ & $1.25 \mathrm{~ns}$ \\
\hline JJA & $1.00 * *$ & $-0.07 \mathrm{~ns}$ & $0.08 \mathrm{~ns}$ & $0.27 \mathrm{~ns}$ & $0.26 \mathrm{~ns}$ & $0.14 \mathrm{~ns}$ & - \\
\hline SON & $0.04 \mathrm{~ns}$ & $-0.05 \mathrm{~ns}$ & $-0.02 \mathrm{~ns}$ & $0.08 \mathrm{~ns}$ & $-0.33^{*}$ & $-0.36 \mathrm{~ns}$ & - \\
\hline Annual & 4.06 ** & $1.29 \mathrm{~ns}$ & $2.11 \mathrm{~ns}$ & $0.29 \mathrm{~ns}$ & $0.08 \mathrm{~ns}$ & $-4.25 \mathrm{~ns}$ & 4.15 ** \\
\hline
\end{tabular}

ns: not significant; $+p<0.10 ;{ }^{*} p<0.05 ; * \star p<0.01 ;-:$ not conclusive.

The remaining months, that is, between August and December, did not show significant trends in any of the stations. It should be emphasized that, for the municipalities of Aguiar and Patos, the trends were not conclusive or not significant in all comparisons (annual, quarterly, and monthly).

In order to apply the traditional Mann-Kendall non-parametric statistical test to a time series, one neglects the correlation between its elements and assumes that the probability distribution should remain the same, that is, it should be a simple random series. When the variance between its elements is null, the test results in non-significant (ns) (Kendall 1975; Mann 1945; Wang et al. 2020a).

For these two weather stations, the coefficients of variation for each series were approximately equal to one, mainly for the months from January to July, indicating that the mean values and the respective standard deviations were close. For the months from August to December, the coefficients of variation were higher. However, these are the months with the lowest precipitation levels, in which the absence of precipitation was repeatedly noted.

Therefore, if in the same series there are many equal elements, the Mann-Kendall test will be unable to detect a significant trend, which is possibly the main reason to explain some non-significant and inconclusive trends in the results of the present study. Other authors consider this as one of the limitations of trend analysis (Wang et al. 2020a; Yue et al. 2002a, b). Therefore, cluster analysis was used to overcome this deficiency, so that it was still possible to investigate the existence of climate change.

Some of the quarterly series showed significant trends, especially of increase in precipitation. In the first quarter, DJF, the increases were significant in Água Branca (1.82 mm/year), Coremas (1.67 mm/year) and Teixeira (1.82 mm/year). In the third quarter, JJA, there was also a significant increase in Água Branca $(1.00 \mathrm{~mm} /$ year) and, in the last quarter, SON, in Princesa Isabel, there was a significant trend of reduction in precipitation ( $0.33 \mathrm{~mm} / \mathrm{year})$.

The results presented through the precipitation data time series are in accordance with those of other studies already published in the literature, in which significant trends are observed in weather stations of Paraíba (Alves et al. 2017; MEDEIROS et al. 2019; Silva et al. 2020).

\subsection{A new approach to cluster analysis}

Cluster analysis was used in order to aggregate in the same cluster the years in which the precipitation distribution showed similarity (similar seasonality, with equivalent monthly values). Two or three clusters were created for each of the weather stations, so that it was possible to identify changes in monthly and annual patterns and compare them to the observed trends. In addition, the 'median year' of each cluster was used as an indicator to confront recent and past periods in the series, in order to better understand the distribution of precipitation over time. These results are presented in Table 3.

Thus, Table 3 presents for each of the stations the number of clusters, the centroids of each monthly series and the annual average (based on the clusters, called Annual) and historical average ( $\mathrm{HA})$. The median year (Med Year) of each cluster indicates the behavior of recent and past periods in relation to precipitation volume. Finally, the percentage number of elements of the series allocated in each cluster (\%) is also presented. 
Table 3

Descriptive information of each cluster for each of the locations in the study area

\begin{tabular}{|c|c|c|c|c|c|c|c|c|c|c|c|c|c|c|c|c|}
\hline Cluster & $\begin{array}{l}\text { Jan } \\
(\mathrm{mm})\end{array}$ & $\begin{array}{l}\text { Feb } \\
(\mathrm{mm})\end{array}$ & $\begin{array}{l}\text { Mar } \\
(\mathrm{mm})\end{array}$ & $\begin{array}{l}\text { Apr } \\
(\mathrm{mm})\end{array}$ & $\begin{array}{l}\text { May } \\
(\mathrm{mm})\end{array}$ & $\begin{array}{l}\text { Jun } \\
\text { (mm) }\end{array}$ & $\begin{array}{l}\text { Jul } \\
(\mathrm{mm})\end{array}$ & $\begin{array}{l}\text { Aug } \\
\text { (mm) }\end{array}$ & $\begin{array}{l}\text { Sep } \\
(\mathrm{mm})\end{array}$ & $\begin{array}{l}\text { Oct } \\
(\mathrm{mm})\end{array}$ & $\begin{array}{l}\text { Nov } \\
(\mathrm{mm})\end{array}$ & $\begin{array}{l}\text { Dec } \\
(\mathrm{mm})\end{array}$ & $\begin{array}{l}\text { Annual } \\
(\mathrm{mm})\end{array}$ & $\begin{array}{l}\text { Med } \\
\text { Year }\end{array}$ & $\%$ & \\
\hline \multirow{4}{*}{$\begin{array}{l}\text { Água } \\
\text { Branca }\end{array}$} & 1 & 68.4 & 88.1 & 145.8 & 100.7 & 56.0 & 40.2 & 28.0 & 9.9 & 5.2 & 2.5 & 14.3 & 9.5 & 568.7 & 1973 & 59.0 \\
\hline & 2 & 93.5 & 134.0 & 157.0 & 172.2 & 81.7 & 76.4 & 71.9 & 14.2 & 4.3 & 22.0 & 2.9 & 96.4 & 926.4 & 1985 & 16.7 \\
\hline & 3 & 74.0 & 117.9 & 229.0 & 193.7 & 177.7 & 55.3 & 40.6 & 28.4 & 16.0 & 7.6 & 26.1 & 16.2 & 982.4 & 1986 & 24.4 \\
\hline & $\mathrm{HA}$ & 74.0 & 103.0 & 168.0 & 135.3 & 89.9 & 49.9 & 38.4 & 15.1 & 7.7 & 7.0 & 15.2 & 25.6 & 729.1 & & \\
\hline \multirow[t]{3}{*}{ Aguiar } & 1 & 72.3 & 140.1 & 214.8 & 147.1 & 45.7 & 17.2 & 8.6 & 3.3 & 0.9 & 7.7 & 22.3 & 44.2 & 724.3 & 1962 & 59.2 \\
\hline & 2 & 160.8 & 156.3 & 224.0 & 253.5 & 144.8 & 45.4 & 25.0 & 7.8 & 3.0 & 10.5 & 11.6 & 37.3 & 1079.9 & 1991 & 40.8 \\
\hline & $\mathrm{HA}$ & 108.4 & 146.7 & 218.6 & 190.5 & 86.1 & 28.7 & 15.3 & 5.1 & 1.8 & 8.9 & 17.9 & 41.4 & 869.4 & & \\
\hline \multirow[t]{4}{*}{ Coremas } & 1 & 109.6 & 133.9 & 203.6 & 132.8 & 47.7 & 26.3 & 16.4 & 2.2 & 0.9 & 2.2 & 5.9 & 19.7 & 701.1 & 1968 & 54.4 \\
\hline & 2 & 80.1 & 107.0 & 184.0 & 166.8 & 96.5 & 48.8 & 16.3 & 16.1 & 11.0 & 47.0 & 19.0 & 60.7 & 853.3 & 1972 & 23.5 \\
\hline & 3 & 140.5 & 199.4 & 327.4 & 294.5 & 158.1 & 33.2 & 19.3 & 5.9 & 2.5 & 2.8 & 50.5 & 41.3 & 1275.4 & 1977 & 22.1 \\
\hline & $\mathrm{HA}$ & 109.5 & 142.0 & 226.3 & 176.5 & 83.5 & 33.1 & 17.0 & 6.3 & 3.6 & 12.9 & 18.8 & 34.1 & 863.6 & & \\
\hline \multirow[t]{3}{*}{ Patos } & 1 & 35.3 & 58.8 & 359.0 & 183.7 & 141.0 & 13.2 & 21.6 & 4.0 & 0.6 & 8.4 & 17.9 & 81.5 & 924.7 & 1992 & 15.4 \\
\hline & 2 & 114.1 & 118.7 & 131.4 & 91.8 & 42.9 & 25.2 & 7.4 & 1.8 & 0.6 & 5.3 & 7.5 & 18.2 & 564.9 & 2000 & 84.6 \\
\hline & $\mathrm{HA}$ & 101.9 & 109.5 & 166.4 & 105.9 & 58.0 & 23.4 & 9.6 & 2.1 & 0.6 & 5.8 & 9.1 & 28.0 & 620.2 & & \\
\hline \multirow{3}{*}{$\begin{array}{l}\text { Princesa } \\
\text { Isabel }\end{array}$} & 1 & 83.5 & 117.3 & 188.8 & 102.9 & 52.9 & 24.0 & 13.2 & 3.0 & 4.5 & 6.3 & 28.6 & 45.9 & 670.8 & 1956 & 51.0 \\
\hline & 2 & 114.1 & 154.8 & 189.5 & 186.5 & 100.5 & 51.4 & 40.8 & 16.4 & 11.4 & 18.9 & 30.6 & 60.0 & 974.9 & 1970 & 49.0 \\
\hline & $\mathrm{HA}$ & 98.5 & 135.7 & 189.2 & 143.9 & 76.2 & 37.4 & 26.7 & 9.6 & 7.9 & 12.5 & 29.6 & 52.8 & 819.9 & & \\
\hline \multirow[t]{3}{*}{ Sousa } & 1 & 179.0 & 272.4 & 226.5 & 335.8 & 171.0 & 45.7 & 25.1 & 9.9 & 16.6 & 24.0 & 13.9 & 56.9 & 1376.7 & 1981 & 22.2 \\
\hline & 2 & 98.3 & 161.5 & 228.8 & 140.0 & 59.4 & 25.9 & 19.6 & 3.0 & 1.8 & 16.9 & 10.7 & 31.5 & 797.4 & 1982 & 77.8 \\
\hline & $\mathrm{HA}$ & 116.3 & 186.1 & 228.3 & 183.5 & 84.2 & 30.3 & 20.8 & 4.5 & 5.0 & 18.5 & 11.4 & 37.1 & 926.1 & & \\
\hline \multirow[t]{4}{*}{ Teixeira } & 1 & 62.9 & 123.1 & 223.5 & 108.4 & 40.0 & 14.0 & 9.5 & 2.4 & 1.7 & 1.4 & 10.7 & 13.4 & 610.9 & 1961 & 69.1 \\
\hline & 2 & 56.1 & 291.8 & 232.4 & 96.3 & 8.5 & 11.4 & 14.2 & 10.5 & 73.4 & 28.5 & 11.7 & 47.7 & 882.3 & 1970 & 2.4 \\
\hline & 3 & 108.5 & 141.9 & 210.5 & 212.5 & 110.7 & 39.7 & 18.8 & 5.9 & 2.0 & 11.8 & 12.9 & 75.1 & 950.3 & 1987 & 28.6 \\
\hline & $\mathrm{HA}$ & 75.7 & 132.5 & 220.0 & 137.8 & 59.5 & 21.3 & 12.3 & 3.6 & 3.5 & 5.0 & 11.4 & 31.9 & 714.3 & & \\
\hline
\end{tabular}

HA: historical average; Med Year: median year.

For the Água Branca station, 3 clusters were created. Cluster 1 (median year 1973) is the one with the lowest value of annual precipitation (568.7 mm), while cluster 3 (1986) has the highest annual value $(982.4 \mathrm{~mm})$. Cluster 2 (1985) is an intermediate group. When comparing the clusters in relation to the volume of precipitation and the median years, it can be inferred that there is an increase in precipitation volumes in the most recent periods (Fig. 3a). This was also observed by trend analysis (Table 2).

In addition to these considerations, in Fig. 3b and Fig. 3c it is possible to visualize how the distribution occurred in each cluster. For cluster 3 (1986) in MAM, the precipitation values were much higher than those of the other clusters, as well as the historical average.

The month of December in cluster 2 (1985) has values much higher than those of the other clusters. In all years belonging to this cluster, the month of December showed high precipitation levels. Higher values were also found in January, February, June, July and December. However, November had the lowest rates for cluster 2 . April is the month with the highest centroid value among the monthly values of the same cluster. Thus, cluster 2 , with $16.7 \%$ of the elements of the series, showed a different behavior compared to the other two clusters, while in more recent years (cluster 3 ) it has been raining greater volumes, but with a seasonality similar to the historical average.

Although no significant trends were detected for the station of Aguiar, two clusters were created by the cluster analysis and it is also noticed that in more recent years, represented by cluster 2 (1991), the volume of precipitation is higher than in the initial years (cluster 1, 1962) (Fig. 4a). The same occurs in quarterly comparisons, except in SON, where the values remain low as in the historical series (Fig. 4b). In cluster 2 (1991), there is a slight shift in the precipitation regime in the rainy season, so that April becomes the rainiest month (Fig. 4c).

In the station of Coremas, by the annual evaluation, it can be seen that the precipitation levels increased gradually. Cluster 3 (1977), the most recent, had the highest values of precipitation (Fig. 5a). This is also observed in the quarterly comparisons of DJF and MAM, that is, in the rainy season (Fig. 5b). According to the trend analysis (Table 2), only the significant increase in DJF was verified. 
It is important to note that, during the rainy months, cluster 2 (1972) had higher values in JJA and SON, as well as in August, September and October. Moreover, cluster 2, composed of $23.5 \%$ of the series elements, is the one which had precipitation levels close to those of cluster 1 (1968) in the rainy season and the highest values in the dry season (Fig. 5c).

The results for the station of Patos are different from those observed so far. Cluster 1 (1992) had higher values; therefore, in the older years of the series the precipitation level was higher than in recent years, represented by cluster 2 (2000) (Fig. 6). Therefore, in recent years it has rained less in the locality of Patos and such reduction was observed mainly in the rainiest quarter of the year (MAM). In contrast to this, by the Mann-Kendall test (Table 2), no significant trends were detected for this station in any month or quarter, nor annually. However, with the cluster analysis approach applied in this study, it is possible to observe how precipitation was distributed over the years/months among the clusters. Thus, it was found that cluster 1 (1992) had much higher values, especially during the rainy season, with values below the average for January, February and June (Fig. 6c).

In Princesa Isabel, as well as in Água Branca, Aguiar and Coremas, the application of cluster analysis shows the increase in precipitation in recent years, especially in the rainy season (Fig. 7). It can be noted that there was an increase in precipitation values from cluster 1 (1956) to cluster 2 (1970), and cluster 2 consisted of $49 \%$ of the years of the series.

All quarters for cluster 1 (1956) had lower values than in cluster 2 (1970), with the largest differences observed in MAM and JJA. Fig. 7c highlights the difference between the monthly precipitation values for the rainy season, except for the peak month of precipitation (March). In the driest period the values are closer.

The Mann-Kendall test proved to be sensitive to increases in precipitation only for the month of July. While for July there was a significant trend of increase $(0.15 \mathrm{~mm} /$ year), in SON there was a decrease of $-0.33 \mathrm{~mm} /$ year in precipitation volumes (Table 2).

It is possible to note that, for the station of Sousa, precipitation values have decreased in recent years: cluster 1 (1981), composed of $22.2 \%$ of the years of the series, had annual precipitation of around $1376.7 \mathrm{~mm}$. For cluster 2 (1982) it was $797.4 \mathrm{~mm}$. However, the difference between centroids was almost zero (1981 and 1982). As pointed out by Alashan (2018), the trend inclinations of each cluster could be detected by comparing their centroid points.

Compared to the Mann-Kendall test, it is possible to note the sensitivity of the trend analysis for the reduction of precipitation in March (-2.92 mm/year), while in the cluster analysis the values were very close in this month for the two clusters (Fig. 8c) and it was not possible to observe this change pointed out by the Mann-Kendall test. This is because of how clusters and their respective centroids are defined in Ward's method. Clusters are formed by minimizing the squares of the component deviations from the average value of each cluster, that is, their centroid (Majerova and Nevima 2017).

All quarters in Sousa showed higher precipitation values for the cluster of the oldest years (cluster 1). This joint analysis clarifies how the changes in rainfall regime occurred, enabling the use of this information to improve the management of plantations, for instance, and a more efficient use of water resources.

It was detected, both by cluster analysis and Mann-Kendall test, an increasing behavior for precipitation in the municipality of Teixeira, especially in the annual comparison (Fig. 9 and Table 2). In the DJF and SON quarters, cluster 2 (1970) stood out, showing the highest averages among the clusters. In MAM and JJA, cluster 3 (1987) was the one which stood out. Increases in precipitation in recent years are more evident in MAM and JJA.

The semi-arid region of northeastern Brazil, which encompasses the study area of the present study, is characterized by the irregular distribution of precipitation, that is, it has high temporal and spatial variability (Lima et al. 2019; Costa et al. 2020a). Annual precipitation is less than 500 mm in a great portion of these semi-arid areas (Oliveira el al. 2017). Cluster analysis, in conjunction with trend analysis, allowed clarifying these changes in precipitation patterns over the years for the studied locations.

Historically, the Northeast has always been affected by prolonged periods of drought or, diametrically and at specific points, by floods (Costa et al. 2020b). The causes of drought in the northeastern semi-arid region of Brazil in 2010-2016 were discussed in the study conducted by Marengo et al. (2018), who observed that after 2012 the droughts became more intense in the northeastern semi-arid region and this may be associated with the singular increase of temperature in the Tropical North Atlantic Ocean, generating an atypical position north of the Intertropical Convergence Zone (itcz), causing less rainfall in northeastern Brazil. Dry years, in general, coincide with the occurrence of the El Niño phenomenon. This scenario aggravates the situation of reservoirs, in addition to agriculture and livestock farming in the region.

On the other hand, the rainiest years for the Northeast region of Brazil were 1964, 1967, 1974, 1985, 1986, 1988, 1989, 1994, 2004 and 2009. In general, this was also observed in the present study, considering the localities which showed significant trends of increase in precipitation, in accordance with cluster analysis, indicating that it has rained more in recent years. One of the possible causes was the transport of moisture from the tropical Atlantic and the Amazon basin to the Brazilian Northeast (Marengo et al. 2018).

However, both droughts and floods cause problems for the population. Therefore, public policies aimed at mitigation and coexistence with extreme weather events are necessary, as they cause important economic losses in this region (Oliveira el al. 2017).

Another point to be highlighted refers to the capacity of widely used methods to recognize trends in climate change studies. In the case of the Mann-Kendall test, one of the advantages of using it is that no assumptions are required about the distribution of data and it is also little sensitive to outliers or limited absence of values in time series. In addition, it becomes more effective with the increase in the slope coefficient of the line given by the Sen's method, that is, with the increase in the amplitude of the observed trend. However, it is inversely proportional to the increase in sample variance, which is very common in precipitation data, and it becomes even less robust when the elements of the series have autocorrelation (Wang et al. 2020a; Yue et al. 2002a, b). 
Cluster analysis was used in the present study to fill this gap of the traditional Mann-Kendall test, since in the hierarchical clustering method the focus is on variability.

\section{Conclusion}

Cluster analysis was applied in this study in a different way from the one usually used in climatology, and this new approach proved to be satisfactory for the proposed objectives. It was possible to identify and group years whose values and seasonal distribution of precipitation were similar to each other, contributing to verify in more detail how climate change is occurring in a given region.

For most of the stations studied (Água Branca, Aguiar, Coremas, Princesa Isabel and Teixeira), the cluster representing the most recent years had the highest annual averages of precipitation, indicating that in recent years it has rained more in the regions where these stations are located. For the station of Patos, the behavior was the opposite, that is, the cluster representing the most recent years had the lowest values. For Sousa, although the Mann-Kendall test indicated a significant trend of decrease for precipitation in March, it was not possible to observe this change using cluster analysis, since the values of the centroids of the clusters were very close. Thus, according to the cluster analysis, there was no temporal difference in precipitation, only the typical variability of this parameter.

According to the trend analysis, the stations showed statistically significant changes of increase or decrease in precipitation in any of the comparisons (annual and/or monthly), except in Aguiar and Patos, where no significant trend was observed. However, cluster analysis can give a different perspective to understanding changes in these situations in which data distribution does not allow the detection of moderate trends. This type of analysis can be useful mainly for data with great interannual variability, such as precipitation data.

Still, when confronting the two methods, it was possible to note a certain consonance between the results. In general, the stations for which significant trends of increase in precipitation were observed were the same ones that had the highest precipitation levels in recent years by the cluster analysis.

This study demonstrated that cluster analysis can be employed in an innovative way to investigate climate change, along with the traditional Mann-Kendall test. Annual and seasonal variation of precipitation were satisfactorily described, providing additional information and a visual-graphic illustration that helps highlight how these changes occurred.

\section{Declarations}

\section{Acknowledgements}

The authors thank the support from the National Council for Scientific and Technological Development (CNPq) through the project 306783/2018-5, the scholarship 142451/2018-5 and the digitalised data from the National Institute of Meteorology (INMET) and the Executive Agency for Water Management (AESA).

Funding information The authors thank the support from the National Council for Scientific and Technological Development (CNPq) through the project 306783/2018-5 and the scholarship 142451/2018-5.

Availability of data and material Data that support the findings of this study are available from the corresponding author, RA, upon request.

Author Attribution Susane Eterna Leite Medeiros: Data curation, Formal analysis, Writing - original draft. Priscila Farias Nilo: Supervision, Validation. Wallysson Klebson de Medeiros Silva: Supervision, Validation. Paula Rose de Araújo Santos: Supervision, Validation. Louise Pereira da Silva: Supervision, Validation. Raphael Abrahão: Conceptualization, Funding acquisition, Methodology, Writing - original draft.

Conflict of interest The authors declare no competing interests.

Ethics approval Not applicable.

Consent to participate Not applicable.

Consent for publication Not applicable.

\section{References}

1. AESA (Agência Executiva de Gestão das Águas do Estado da Paraíba) Executive Agency for Water Management of the State of Paraíba. Plano Estadual de Recursos Hídricos - Relatório final. João Pessoa (2009) http://www.aesa.pb.gov.br/perh/

2. Alashan S (2018) An improved version of innovative trend analyses. Arab J Geosci 11(3):1-6. https://doi.org/10.1007/s12517-018-3393-x

3. Alvares CA, Stape JL, Sentelhas PC, Gonçalves JDM, Sparovek G (2013) Köppen's climate classification map for Brazil. Meteorol Z 22(6):711-728. https://doi.org/10.1127/0941-2948/2013/0507

4. Alves TLB, de Azevedo PV, dos Santos CAC (2017) Influence of climate variability on land degradation (desertification) in the watershed of the upper Paraíba River. Theoret Appl Climatol 127(3):741-751. https://doi.org/10.1007/s00704-015-1661-1

5. Beck HE, Zimmermann NE, McVicar TR, Vergopolan N, Berg A, Wood EF (2018) Present and future Köppen-Geiger climate classification maps at 1-km resolution. Scientific data 5(1):1-12. https://doi.org/10.1038/sdata.2018.214

Page $7 / 12$ 
6. Betts AK, Desjardins R, Worth D, Beckage B (2014) Climate coupling between temperature, humidity, precipitation, and cloud cover over the Canadian Prairies. Journal of Geophysical Research: Atmospheres 119(23):305-326. https://doi.org/10.1002/2014JD022511

7. Chervenkov H, Slavov K (2019) Theil-Sen estimator vs. ordinary least squares-trend analysis for selected ETCCDI climate indices. Comptes Rendus Acad Bulg Sci 72:47-54. https://doi.org/10.7546/CRABS.2019.01.06

8. Costa MDS, Oliveira-Júnior JFD, Santos PJD, Filho Correia WLF, Gois G, Blanco CJC, Teodoro PE, Junior Silva CA, SantiagO DB, Souza EO, Jardim AMRF (2020a) Rainfall extremes and drought in Northeast Brazil and its relationship with El Niño-Southern Oscillation. Int J Climatol 41:E2111-E2135. https://doi.org/10.1002/joc.6835

9. Costa RL, de Mello Baptista GM, Gomes HB, Silva FDS, Junior Rocha RL, Salvador MA, Herdies DL (2020b) Analysis of climate extremes indices over northeast Brazil from 1961 to 2014. Weather and Climate Extremes 28:100254. https://doi.org/10.1016/j.wace.2020.100254

10. Dogru T, Marchio EA, Bulut U, Suess C (2019) Climate change: Vulnerability and resilience of tourism and the entire economy. Tour Manag $72: 292-305$. https://doi.org/10.1016/j.tourman.2018.12.010

11. Gedefaw M, Yan D, Wang H, Qin T, Girma A, Abiyu A, Batsuren D (2018) Innovative trend analysis of annual and seasonal rainfall variability in Amhara regional state, Ethiopia. Atmosphere 9(9):326. https://doi.org/10.3390/atmos9090326

12. Hair JF Jr, Black WC, Babin BJ, Anderson RE (2011) Multivariate Data Analysis. PrenticeHall, New Jersey

13. IBGE (Instituto Brasileiro de Geografia e Estatística) Brazilian Institute of Geography and Statistics. Divisão Regional do Brasil em Regiões Geográficas Imediatas e Regiões Geográficas Intermediárias (2017) Rio de Janeiro, IBGE, 2017. https://www.ibge.gov.br/apps/regioes_geograficas/

14. Kendall MG (1975) Rank correlation methods. Charles Griffin, London

15. Krzysztof B, Pavol N, Agnieszka H, Olesya S, Anna B, Katarina M (2020) Influence of geographical factors on thermal stress in northern Carpathians. Int J Biometeorol 65:1553-1566. https://doi.org/10.1007/s00484-020-02011-x

16. Lima FJL, Martins FR, Costa RS, Gonçalves AR, dos Santos APP, Pereira EB (2019) The seasonal variability and trends for the surface solar irradiation in northeastern region of Brazil. Sustain Energy Technol Assess 35:335-346. https://doi.org/10.1016/j.seta.2019.08.006

17. Liu Q, Liu W, Tang J, Deng M, Liu Y (2019) Permutation-test-based clustering method for detection of dynamic patterns in Spatio-temporal datasets. Comput Environ Urban Syst 75:204-216. https://doi.org/10.1016/j.compenvurbsys.2019.02.007

18. Majerova I, Nevima J (2017) The measurement of human development using the Ward method of cluster analysis. Journal of International Studies 10(2):239-257. https://doi.org/10.14254/2071-8330.2017/10-2/17

19. Mann HB (1945) Nonparametric tests against trend. Econometrica: Journal of the econometric society $13(3): 245-259$. https://doi.org/10.2307/1907187

20. Marengo JA, Souza CM Jr, Thonicke K, Burton C, Halladay K, Betts RA, Alves LM, Soares WR (2018) Changes in climate and land use over the Amazon region: current and future variability and trends. Frontiers in Earth Science 6:1-21. https://doi.org/10.3389/feart.2018.00228

21. Medeiros SEL, Abrahão R, da Silva LP, Silva WKM (2019) Comparison between observed and estimated data to assess air temperature variability and trends in the Sertão Paraibano mesoregion (Brazil). Environ Monit Assess 191(2):63. https://doi.org/10.1007/s10661-019-7207-8

22. Medeiros SEL, Abrahão R, García-Garizábal I, Peixoto IMBM, Silva LPD (2018) Assessment of precipitation trends in the Sertão Paraibano Mesoregion. Revista Brasileira de Meteorologia 33:344-352. https://doi.org/10.1590/0102-7786332016

23. Mtilatila L, Bronstert A, Bürger G, Vormoor K (2020) Meteorological and hydrological drought assessment in Lake Malawi and Shire River basins (19702013). Hydrol Sci J 65(16):2750-2764. https://doi.org/10.1080/02626667.2020.1837384

24. Oliveira PTD, Silva CS, Lima KC (2017) Climatology and trend analysis of extreme precipitation in subregions of Northeast Brazil. Theoret Appl Climatol 130(1):77-90. https://doi.org/10.1007/s00704-016-1865-z

25. Parker L, Bourgoin C, Martinez-Valle A, Läderach P (2019) Vulnerability of the agricultural sector to climate change: The development of a pan-tropical Climate Risk Vulnerability Assessment to inform sub-national decision making. PLoS ONE 14(3):e0213641.

https://doi.org/10.1371/journal.pone.0213641

26. Sen PK (1968) Estimates of the regression coefficient based on Kendall's tau. J Am Stat Assoc 63(324):1379-1389. https://doi.org/10.1080/01621459.1968.10480934

27. Shahid M, Rahman KU (2021) Identifying the annual and seasonal trends of hydrological and climatic variables in the Indus Basin Pakistan. Asia-Pac $J$ Atmos Sci 57(2):191-205. https://doi.org/10.1007/s13143-020-00194-2

28. Silva WKM, Medeiros SEL, Silva LP, Coelho Junior LM, Abrahão R (2020) Sugarcane production and climate trends in Paraíba state (Brazil). Environ Monit Assess 192:1-12. https://doi.org/10.1007/s10661-020-08358-3

29. Sneyers R (1992) On the use of statistical analysis for the objective determination of climate change. Meteorol Z 1(5):247-256. https://doi.org/10.1127/metz/1/1992/247

30. Solaun K, Cerdá E (2019) Climate change impacts on renewable energy generation. A review of quantitative projections. Renew Sustain Energy Rev 116:109415. https://doi.org/10.1016/j.rser.2019.109415

31. Wang F, Shao W, Yu H, Kan G, He X, Zhang D, Ren M, Wang G (2020a) Re-evaluation of the power of the mann-kendall test for detecting monotonic trends in hydrometeorological time series. Frontiers in Earth Science 8:14. https://doi.org/10.3389/feart.2020.00014

32. Wang Y, Xu Y, Tabari H, Wang J, Wang Q, Song S, Hu Z (2020b) Innovative trend analysis of annual and seasonal rainfall in the Yangtze River Delta, eastern China. Atmos Res 231:104673. https://doi.org/10.1016/j.atmosres.2019.104673

33. Yue S, Pilon P, Cavadias G (2002a) Power of the Mann-Kendall and Spearman's rho tests for detecting monotonic trends in hydrological series. J Hydrol 259(1-4):254-271. https://doi.org/10.1016/S0022-1694(01)00594-7

Page $8 / 12$ 
34. Yue S, Pilon P, Phinney B, Cavadias G (2002b) The influence of autocorrelation on the ability to detect trend in hydrological series. Hydrol Process 16(9):1807-1829. https://doi.org/10.1002/hyp.1095

\section{Figures}

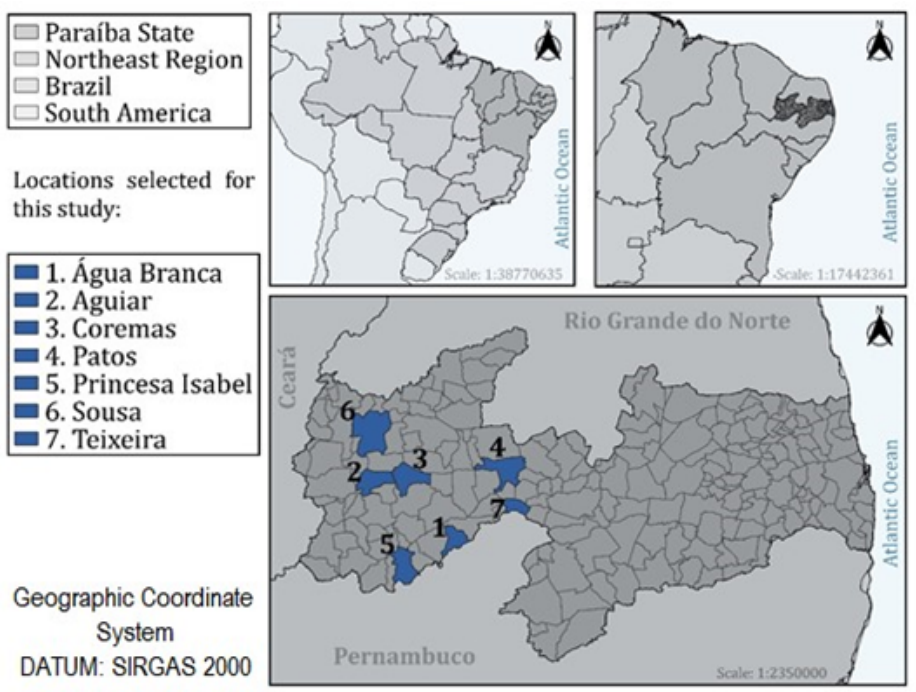

\section{Figure 1}

Studied areas in the northeastern semi-arid region located in the state of Paraíba (Brazil)
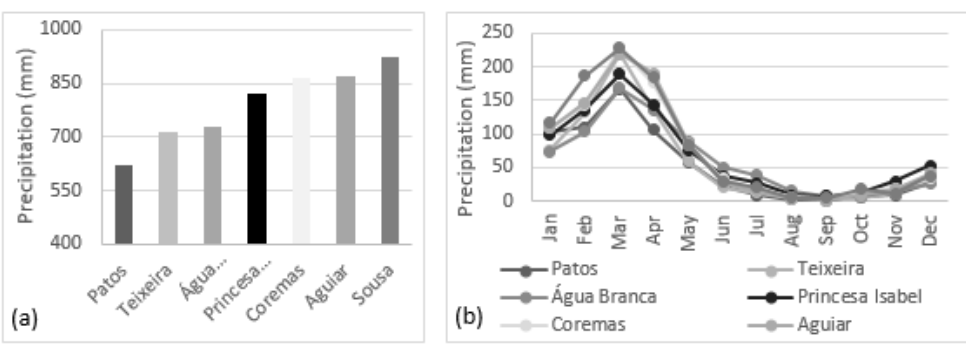

Figure 2

Average annual precipitation (a) and average monthly behavior (b) for the studied stations with data between 1912 and 2018 from weather stations maintained by AESA and inmet
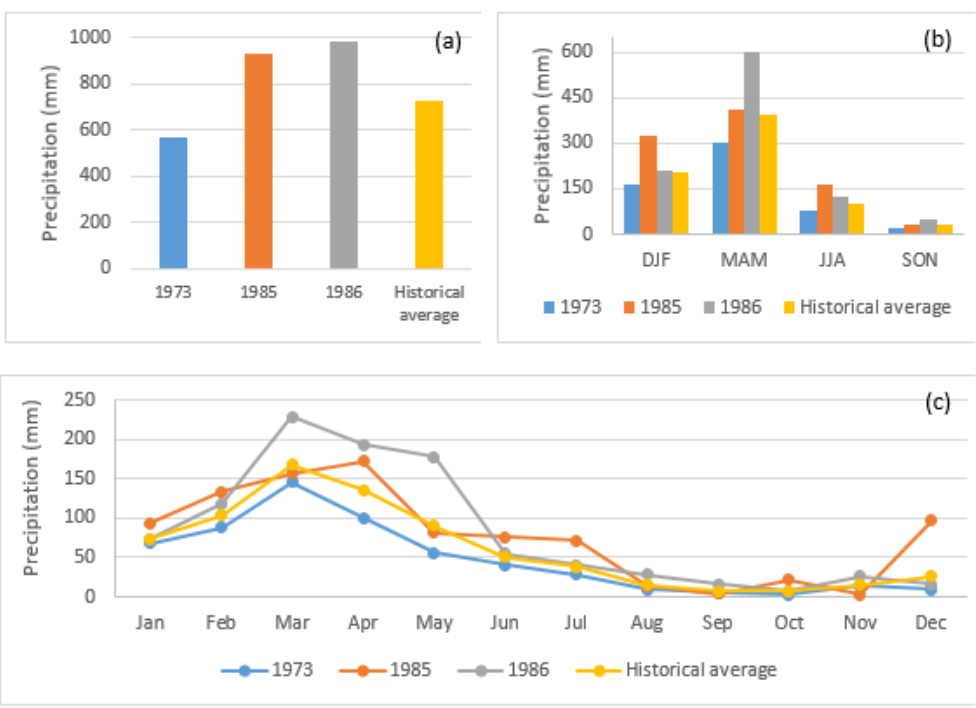
Figure 3

Centroid of each cluster created from cluster analysis and historical average of precipitation (a), quarterly precipitation (b) and monthly precipitation (c) for Água Branca
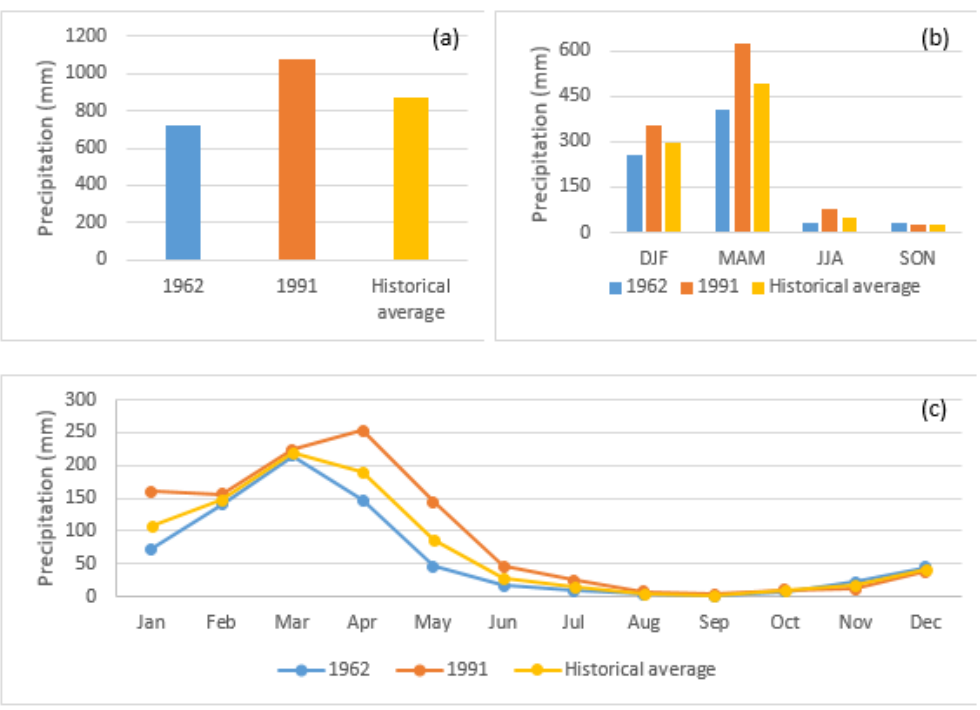

\section{Figure 4}

Centroid of each cluster created from cluster analysis and historical average of the annual precipitation (a), quarterly precipitation (b) and monthly precipitation (c) for Aguiar

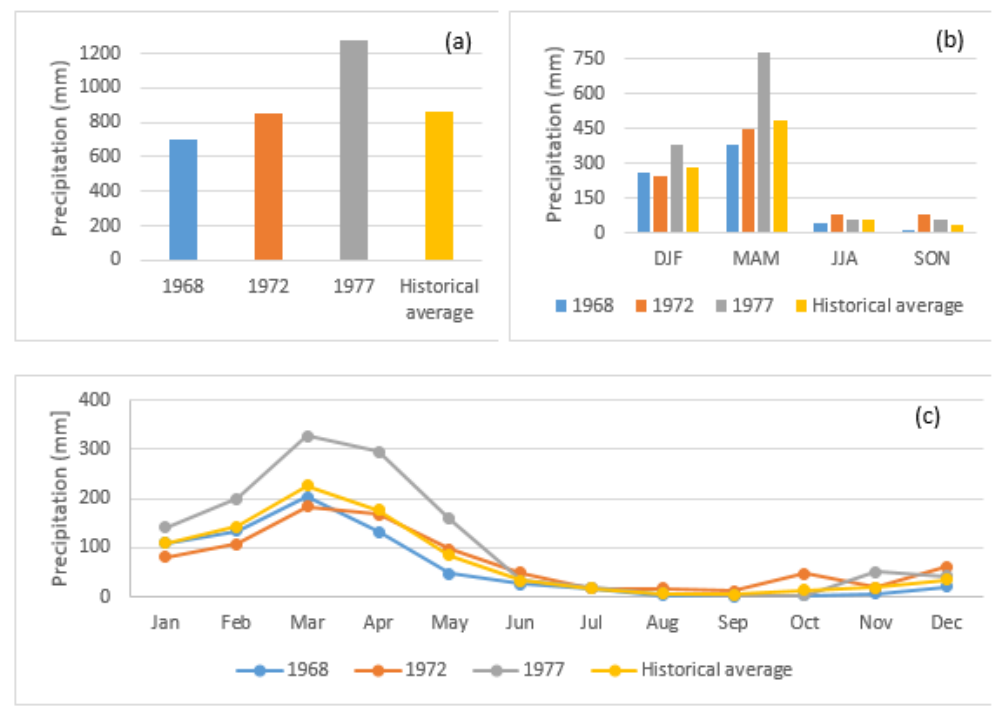

\section{Figure 5}

Centroid of each cluster created from cluster analysis and historical average of precipitation (a), quarterly precipitation (b) and monthly precipitation (c) for Coremas 

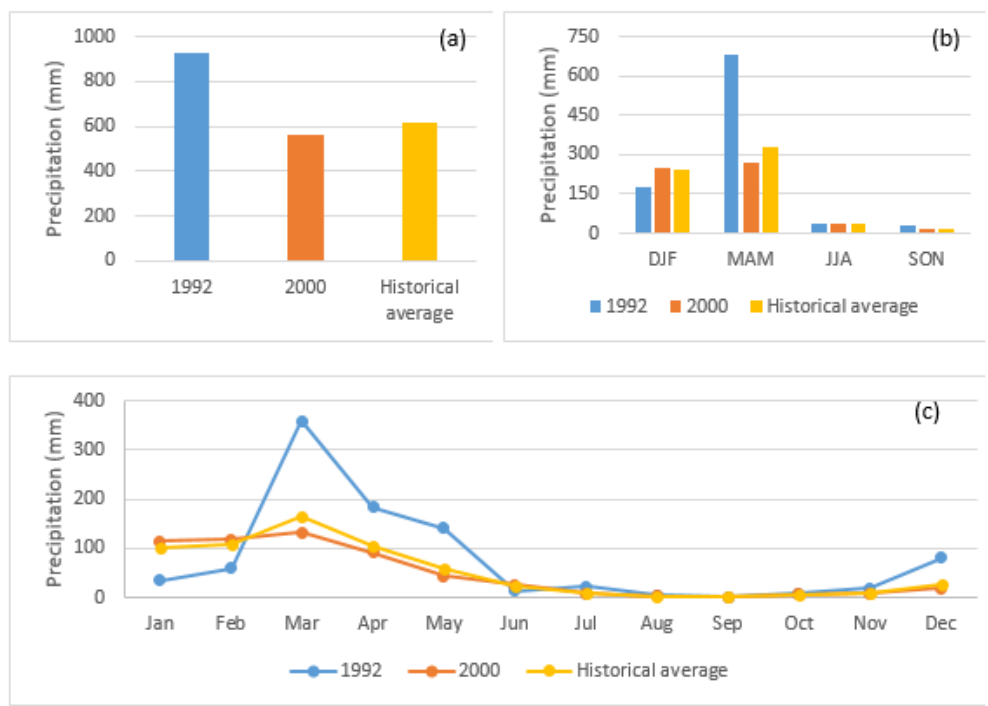

\section{Figure 6}

Centroid of each cluster created from cluster analysis and historical average of precipitation (a), quarterly precipitation (b) and monthly precipitation (c) for Patos
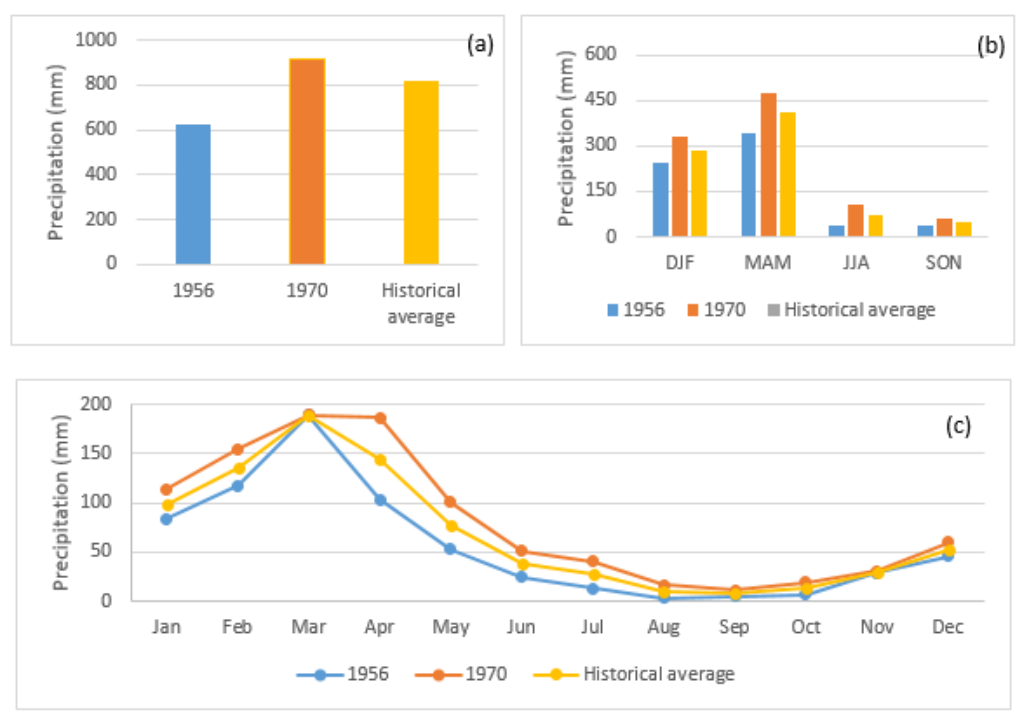

\section{Figure 7}

Centroid of each cluster created from cluster analysis and historical average of precipitation (a), quarterly precipitation (b) and monthly precipitation (c) for Princesa Isabel 

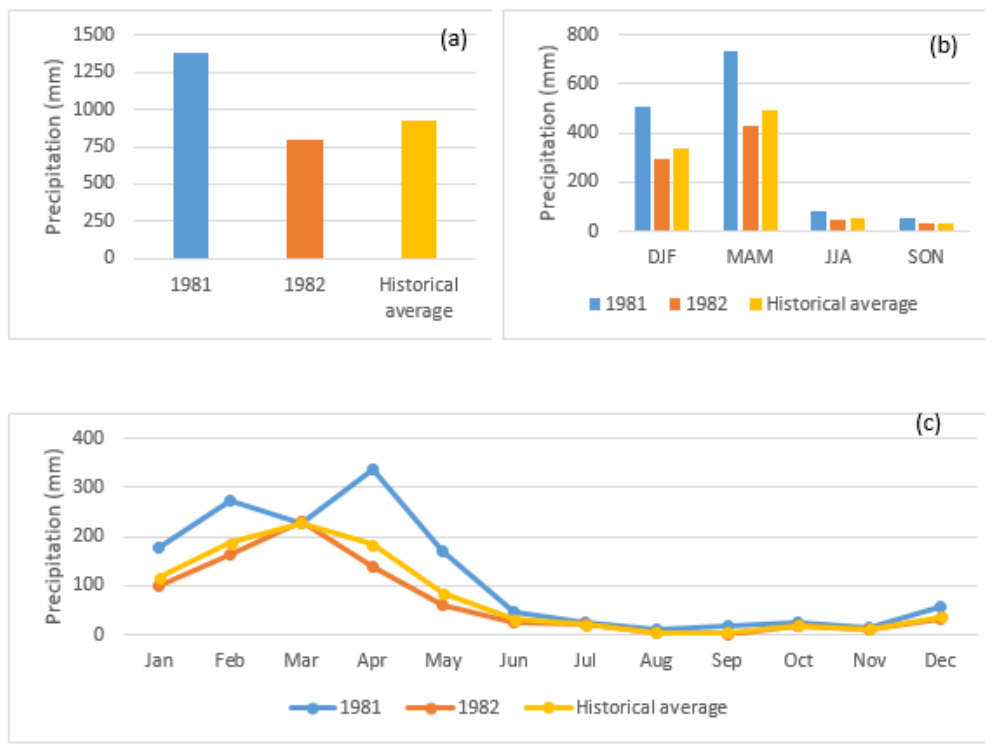

\section{Figure 8}

Centroid of each cluster created from cluster analysis and historical average of precipitation (a), quarterly precipitation (b) and monthly precipitation (c) for Sousa
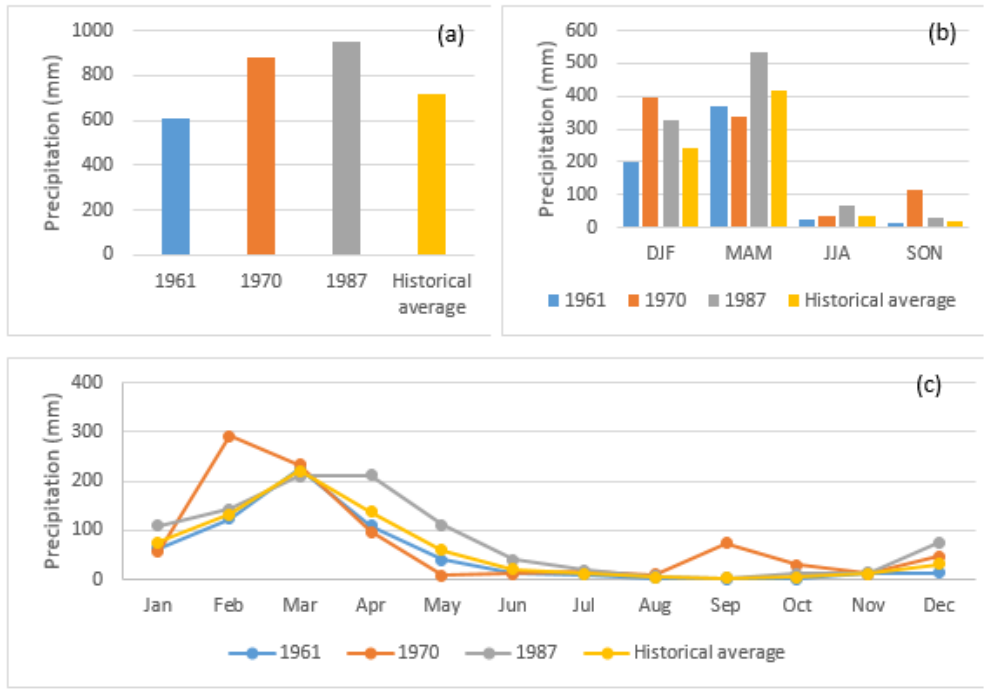

\section{Figure 9}

Centroid of each cluster created from cluster analysis and historical average of precipitation (a), quarterly precipitation (b) and monthly precipitation (c) for Teixeira 